\title{
Implementing Reader-Response Theory: An Alternative Way of Teaching Literature Research Report on the Reading of Booker T Washington's Up from Slavery*
}

\author{
Ririn Kurnia Trisnawati \\ Islamic University of Indonesia
}

\begin{abstract}
Reader-response theory shifts the critical focus from a text to a reader. It diverts the emphasis away from the text as the sole determiner of meaning to the significance of the reader as an essential participant in the reading process and the creation of meaning. Thus, both explanations place a reader as an active participant along with the text in the production of interpretation of that literary work from the point of view of the reader-response theory.

As a result, if teaching literature is to accommodate the students' role in making interpretation, it is supposed to place them as the active readers to interpret and shape the meaning of that particular literary works; it is not preaching or directing them into a specific meaning decided previously. Students as the active readers must be given opportunity and space to develop their opinion and argumentation to shape and define what a particular text means to them. Therefore, by understanding and applying reader-response theory in teaching and learning literature in the classroom, at the same time, teachers could have a different teaching and learning method e.g. learners-centered learning.

This paper is going to depict how the understanding of a literary work's meaning and interpretation is composed by the readers-the students; how the students could function themselves as active readers who successfully manage to interpret the literary work based on their responses and how finally this particular group of readers could finally agree on the particular interpretation. Besides, it is to place students both as the readers and learners
\end{abstract}

* The paper has been presented in the $2^{\mathrm{od}}$ RAFIL (Reading Asia, Forging Identities in Literature) International Conference on East-West hosted by Sanata Dharma University in Yogyakarta Indonesia. 
of a discussed literary work as the center of teaching and learning literature as they are the active agent to shape the literary work's meaning. By doing so, teachers are also the ones who encourage students to express their opinions, and eventually students' critical thinking could be embraced. Hence, teaching and learning literature could become an interactive and collaborative process.

Keywords: reader-response theory, interpretation, students and active readers.

\section{A. Three Critical Focuses of Studying Literature: Seeking an Alternative}

As it may happen to any field of studies, the study of literature could also be viewed from various points of view using various ranges of theories and approaches. However, there are three distinctive and critical focuses that differentiate the study of literature. These three subject matters will eventually direct and guide the usage and implementation of a particular theory or approach. Literature is studied by scrutinizing its three critical focuses e.g. the literary text, the author and its readers although some might add that the universe and its relation to literary works have deserved to fall into the forth critical focus.

In his book The Mirror and the Lamp, M.H. Abrams (1953:6) has divided the critical focuses into four elements e.g. the work, the artistic product itself; the artist, the artificer of the human product; the universe, the product and all ideas, material things and the super sensible essence relation to the work; and the audienze, the readers to whom the work is addressed. Further, he emphasizes that they can be spread out into various theories for comparison. The universe could lead to the mimetic theories because the explanation of art is as essentially an imitation of aspects in the universe. It means that every single work of art created is actually an imitation of the universe. Then, it could be also said that a literary work is written, somehow and sometimes, in response to what happens to the society - the universe and its reflection. As a result, a study of a literary text could also dig up the study of the society within the works by employing sociology of literature and other approaches dealing with such issues, for instance. The next is studying the literary work by seeing who the author is or solely by looking up the text only. The former will guide leamers to the introduction of expressive theories whereas the latter could lead to the concern on the text by looking up its language, 
structure and other text-oriented issues. The last critical focus e.g. the reader might become the main concern of this writing since readers are considered the main source of literary work study. Literary texts are addressed to readers, and a text constitutes nothing without readers. Besides, study on readers and their interpretation seem to be rarely conducted. Therefore, this writing will promote something different to experience a slight variety in the discussion of a literary work study from the point of view of readers by employing reader-response theory.

\section{B. The Reader-Response Theory and Learners-Centered Classroom: The Objectives}

Although there are various studies that can be conducted to shape the interpretation of a literary work, the writer puts her interest in the reader-response theory. She is interested in this study because she means to contribute the fact that a reader, indeed, has a role as the re-creator that may have been forgotten. Besides, she wants to offer an alternative approach that revealing and scrutinizing the interpretation of a certain literary work can be done in such a different way. This different way is by reading closely to readers' responses toward a certain literary work, not merely reading the literary work itself, and forgetting a readers' role as an active participant. Further proposal of conducting the study of literature by employing reader-response theory is to propose reader-response theory as an alternative to teach literature in the classroom. The method is using so-called learners-centered classroom. It is because both share many benefits and outcome in common. Hence, as the outcome, studying literature by employing readerresponse theory in learners-centered classroom could be interactive and collaborative because it involves students/ readers' opinions, interpretation, and active participation.

Based on those benefits of applying reader-response theory and learnerscentered classroom to teach and to study a particular literary text, it is worth trying to conduct a research employing that particular combination. Both will suggest different nuance and new atmosphere of learning and teaching a literary work by employing reader-response theory and of teaching the literary text by conducting learners-centered classroom. This writing is the research report writing. It is composed based on a particular research done using the combination of readerresponse theory and learners-centered learning. The literary work under study is 
Booker. T Washington's Up from Slavery. The work is an autobiography. This autobiography is studied using reader-response theory meaning that its interpretation and meaning are shaped by analyzing the readers' response.

Meanwhile, the readers/ students involved are the students of English Study Program Diploma 3 FPSB UII who are joining English Literature Club (Elite-Club). Although this is a club, indeed, the students involve in this "class" have been very satisfactorily perfectly called as students. They managed to join the club as they joined the classroom in any subjects of lesson they have taken. The supervisor of this club-the writer-has designed several meetings to study Booker T Washington's Up from Slävery by conducting a learners-centered classroom. The meetings were purposely conducted differently from the previous meetings in the Elite-Club. The main reason is to see, understand, and realize that there is a possibility. of learning and teaching a literary text using the readers/students as the source of information and knowledge.

\section{On Readers and Reader-Response Theory}

The critical main focus of the reader-response theory is different from that of other approaches in analyzing and studying the meaning or the interpretation of a literary work. Iser in Thompson (1992:12) illustrates that the reader-response theory shifts the critical focus from the text to the reader. Hence, the point of difference lies on the reader as the focus of analysis. In the same way, Bressler (1999:67) also explains that the reader-response theory diverts the emphasis away from the text as the sole determiner of meaning to the significance of the reader as an essential participant in the reading process and the creation of meaning. As a result, both explanations above place a reader of a literary work as an active participant along with the text in the production of interpretation of that literary work from the point of view of the reader-response theory. Furthermore, this placing a reader becomes an active participant will then give another view of a reader's role itself.

In literature along with its various genres, each genre is actually dedicated to its readers, and those readers may bring various roles to a literary work. Basically, a reader is the one who reads and gives meaning to the literary work. At the mean time, during or after the reading process, whether a reader will sit 
passively or move actively determines his or her particular role as a reader. A role of a reader that used to be believed and assumed to be the only possible role is the passive role of a reader. This illustrates a reader who reads a literary work as if he or she were a sport spectator sitting passively, just absorbing the contents of the artistic creation of that literary work, and allowing it to dominate his or her own thoughts. Such a reader brings little to the text; therefore, it is the text that provides all that is needed to interpret a certain meaning of the text itself. It will lead to the critical focus of studying literature to the text-oriented. In short, readers' role is so passive that he or she is not involved in shaping the interpretation of a literary work.

On the other hand, another role of a reader that may have enlightened the study of a literary work and that becomes the basic assumption of the readerresponse theory is the role of a reader as the active audience, or the re-creator of the literary work he or she reads. This role is closely related to the further action taken by a reader, namely recreating the literary work itself. The view on the importance of readers' role has enlightened the study of a literary work since 1920 s, when for the first time Richards proposed to catalogue the readers' strategies for understanding and interpreting poetry (Davis, 1986:345). Unlike the previous concern of the study of a literary work, he turned directly to the steps readers go through as they read. He evaluated and analyzed his students' free responses and he came to a certain conclusion. He acknowledged that a reader might bring to the text a vast array of ideas amassed through life's experience, including previous literary experience, and apply such information or experience to the text.

By doing so, the reader is no longer considered as the passive receiver of a text, but he or she is an active participant in the creation of a text's meaning. This conclusion becomes a turning point from the belief of passive role of a reader to the active one in which he acts as the re-creator of the text he reads. Meanwhile, from the late 1960 s through the present, modern reader-response theory has emerged and the meaning of readers as the re-creators concentrates exclusively on what readers do next and how they do it. Such a belief of placing the reader as the recreator may become one important view to consider that a reader can do more than just reading a literary work. It means that placing the role of a reader as the recreator makes the reader as the primary concern of the study of a literary work. 
Concerning the role of a reader as the re-creator, Evans (1987:23) explains that the role of the reader as a re-creator is mainly a duty to recreate the literary work he or she reads after the reading process. Further, Evans aiso implies that placing the reader as the re-creator is one way to shape and to understand the interpretation of the printed text of the literary work. The reason is, just like what Iser in Evan (1987;23) writes, the meaning of literary works remains related to what the printed text says, but it still requires the creative imagination of the reader to put it all together. In short, it is believed that the interpretation of a literary work is created by the reader of the literary wok as a creative imagination. Thus, how a certain literary work tells and shows the reader its aim, still, the meaning or the interpretation of it depends on the creative imagination experienced by the reader.

Responding to a literary work shows shaping the interpretation of a literary work done by a reader. Those responses are stated by the aid of response statements. The process of responding or giving comments is basically the main idea of shaping and analyzing the meaning or the interpretation of the literary work from the point of view of the reader-response theory. In other words, the readerresponse theory is the device to reach and to analyze the re-creator role of a reader in the production of the interpretation of a literary work.

\section{Implementing Reader-Response Theory in Studying and Teaching Literature}

Based on the nature of reader-response theory, it is believed that readers are the ones that shape and become the core source of learning a particular literary text. Hence, studying and teaching literature using reader-response approach could not be more interesting and interactive. If teaching literature is to accommodate the students' role in making interpretation, it is supposed to place them as the active readers to interpret and shape the meaning of that particular literary works. The alternative of studying and teaching literature is not preaching or directing them into a specific meaning decided previously any longer. Studying literature is not based on the teacher's "ideology" or interpretation prepared before she enters the classroom. Teachers will have to give students opportunity and space to develop their opinion and argumentation to shape and define what a particular text means to them as students are the active readers. Besides, the procedure of applying readerresponse theory will make readers more engage in the understanding of the literary 
work, mingle with other readers, and Iearn various opinions, responses, and insight from other readers/students instead of single interpretation only from the teacher.

As Tompkins (1980:ix) has explained, the procedure involves the following terms namely reader, the reading process and response to mark out an area for investigation of a literary work. It means placing readers as a focus of analysis must involve their responses to a literary work after they pass their reading process on that literary work. It is because the responses given by readers are seen as a product of new creation upon the text they have read that later may become the interpretation of that single text. Meanwhile, Rosenblatt in Bressler (1998:66) defines that the reading process involves a reader and a text for both of them will interact one another. She elaborates that a text acts as a stimulus for eliciting various past experiences, thoughts and subjective motives from readers whereas a text shapes the reader's experiences, selects and limits those experiences that best comfort to that text. Continuing the reading process and giving responses, readers/students involved in the learning of a literary work will have to engage and mingle in the community of readers. In relation with this, Bleich (1978:135) defines a community as some people who already read, negotiate, and agree each other.

A community of readers consists of readers who have similarities of concerns and common interest and later on they have already agreed on particular statement one another. This community of readers will also trigger the readers/ students' communicative skills as they have to respond, give comment, and learn each others. Eventually, the process of studying, learning, and shaping the meaning of literary work will be more interactive and collaborative by employing readerresponse theory and its procedure. In practical level, this procedure is likely similar to what learners-centered learning does exercise in a teaching and learning method.

Therefore, by understanding and applying reader-response theory in teaching and learning literature in the classroom, at the same time, teachers could have a different teaching and learning method e.g. learners-centered learning. It is because reader-response theory shares points in common with learners-centered learning. Both place readers and students as the main source, primary agents and active participants in their focus of studying a literary work and its teaching and learning process. 
The concept of students/ learners-centered learning or Learners-Center Classroom (LCC) has been recognized as an advancement of teaching and learning theories and approached since 1095. The premise of this approach/ teaching method is to place and to encourage learners to be active and enthusiastic in the classroom. This is due to the fact that the former teaching method, especially language and literature subjects, has made students/learners reluctant to be active. It is when teachers have become the solely center attention and have played a dominant role as the source of knowledge and interpretation. As a result, this condition discourages the activeness and optimism of the students and leads to hamper the spirit of learning in the long run.

Further, in this case, according to McCombs and Whisler (1997:9) LCC has been defined as:

The perspective that couples a focus on individual learners (their heredity, experiences, perspectives, backgrounds, talents, interests, capacities, and needs) with a focus on learning (the best available knowledge about learning and how it occurs and about teachïn practices that are most effective in promoting the highest levels of motivation, learning, and achievement for all learners).

It gives further understanding that LCC is a combination of focus among students by considering their various background and interest involved within and during the teaching and leaming process in order to achieve a certain level of knowledge and understanding. This brings further impacts that by employing LCC the roles of teachers will be a bit different from those of previous method of teaching e.g. they will function also as guide and or facilitator.

Here, students will be the readers and the active learners whereas teachers will be the moderator, guide, and facilitator of creating and shaping the meaning and responses upon that particular literary piece. By vocalizing various responses, opinions, and interpretation, students are constructing and presenting the embryo or earlier knowledge of the text's interpretation. Students will interact each other by giving and asking opinion; therefore, they will be actively engaged and involved. Students will not directly gain knowledge from their teachers; they will transfer the knowledge from their fellow students. Hence, the outcome is having active, interactive, and autonomous students with their deep and independent learning in a very cooperative and collaborative classroom. 
Furthermore, the resonance between reader-response theory and LCC carry on the several terms exercised in the implementation of LCC. If LCC is implemented, there are some other benefits that can be taken into account. They are related to psychological principles in LCC e.g. metacognitive and cognitive, affective, developmental, personal and social as well as individual differences. McCombs and Whisler (1997:5) have defined them deeper. Metacognitive and cognitive psychological principles justify the nature of LCC. In a learners-centered classroom, there is a seeking of knowledge process which is active, personal, and meaningful. Students' cognitive power is also exposed in a way that they have to think about thinking - knowledge and interpretation of the literary work, and it requires significant higher-order thinking. As a result, students have to facilitate themselves with creativity and critical thinking in the teaching and learning process as well as achieving the interpretation of that literary work.

The next exposed aspect is affective psychological background. The affective motive is related to beliefs, emotions, and motivations which influence the way students understand, respond, and achieve successful learning process. Affective motive is a challenge that must grow in each individual of learners. Further, in the LCC, students' affective motive will be always sharpened autonomously because students are the focus/ center of the learning process as well as in the process of understanding the interpretation and the meaning of that literary work being studied.

Some others are developmental, personal, social, and individual differences. In a classroom undergoing learner-centered learning, the developmental factor will place students/learners as an agent of change. They must always develop and are willingly to develop in order to broaden the insight and catch up with their fellow students. LCC is also possible to advance their personal and social motives. Developmental and personal factors/motives are somewhat related each other. When students are willingly to develop themselves during the teaching and leaming process, they will benefit from that development meaning that their development will influence their personal ịndividual. As a result, by conducting LCC in teaching and learning literature, students will develop their academic insight and take the benefits for their individual.

In practice, LCC could also trigger students' social motives. When learners-centered classroom is applied, they will share knowledge with others and 
study the particular subjects that have been designed. Besides, when it is combined with reader-response theory as it is to study a literary piece; students are creating what so-called community of readers. In this community of readers, students will actively engage, give their responses and opinions over the literary work, and negotiate on the meaning and its interpretation. Hence, social motive is sharpened as they are having the discussion and negotiation.

However, there are students with different competence that can not be simply neglected. Teachers who are employing LCC and reader-response theory must be able to fully become the facilitator and moderator for the students. Teachers are supposed to be able to bridge the handicapped students; they must be able to create a collaborative classroom, too. In this case, LCC has put the concern with the existence of teachers in the learning process. As a conclusion, LCC has its specific concern on the teaching and learning method, particularly on the teaching and learning of literature. It could be better when it is combined with the application of reader-response theory as they have shared many things in common. LCC and reader-response theory have a very high possibility to encourage students to be critical, independent and potential students in learning literary works.

\section{E. On the Study of BookerT Washington's Up from Slavery and its readers}

The literary work under study is Booker T Washington's $U_{p}$ from Slavery. It is an autobiography written by one of the best African American literary figures. 'This masterpiece consists of several chapters depicting how Washington had undergone his life as a slave in Franklin County, Virginia, had been a sporadically student to achieve fundamental literacy, and had gained success as a truly educator for Black people, eventually. This sequence of life, issues on slavery, oppression, and racial discrimination are the major theme that is depicted throughout the autobiography. This is one of universal issues that worth analyzing and gaining attention from its readers. Therefore, this work was chosen though there was no prior information about the theme of the autobiography. It means that readers/ students were given the work to read without telling them what it was about. This is one part of consequences to employ the reader-response theory i.e. readers are not guided by some preconceptions that later might influence them in a way responding and giving interpretation of the autobiography. Hence, readers were free to assume the context and the theme of the work. 
The readers or the students are some students joining the Elite-Club. They were students of the first year and the third year. There were no special requirements to join the club and no limitation on the number of the club members. The students actively participated in this club were about 6 (six) students. The club ran for one month only as the writer gained and collected the data. The students' activities were receiving the text and were given a week to finish the given text-only some chapters of the autobiography; in addition, they read individually and then gathered in a classroom to discuss the work after a week. They were also writing their responses and commenting on others' responses and interpretation on the work. This activity has remarked the application of reader-response theory in the study of a literary text. Further, for several meetings, students were gathering, transferring knowledge on their responses and opinions, and learning each other, too. At this point, they placed themselves as the source of information. Until in the last meeting, the gathering was purposely to discuss the final interpretation as the main meaning of that particular autobiography.

Meanwhile, the writer that happened to be the moderator of the club and the teacher of the classroom was playing her roles as facilitator and guide. She only gave comment and contribution when the discussion was out of the topic and when the students asked her for confirmation and new information. This situation has been in line with the nature of learners-centered classroom. Besides, in order to undergo the valid data collection, she did that on purpose meaning that she intentionally gave less contribution and involvement on the teaching and learning process on the discussion of Washington's autobiography Up from Slavery.

\section{F. Finding and Analysis on Students' Response in the Students-Centered Classroom}

At least, there are three identical responses given by the readers that can be taken into account and analyzed as the interpretation and meaning of Washington's autobiography Up from Slavery. They are the language used is easy to understand; the autobiography depicts the actual living as a slave and slave's life journey in the era of slavery in the United States; and, the autobiography gives the readers/ students details fight and struggle that a slave had to face to achieve his dreams. 
The first is mentioned directly by two students. Their responses are "it is nice story. The author makes this story with simple sentences, so it is not really difficult for me to read", said Zulianty and Deni wrote that it was well written and easy to understand. Getting these responses, the teacher needed to confirm to other students by asking the question whether the language was easy to understand or not. Apparently, other students agreed to acknowledge that the language was simple so that it was easy to read and to understand though some found that there were many new words and terms that they did not understand. Facing this, the teacher gave her role as a facilitator by explaining some terms that students found it difficult such as Civil War in the United States, Black Race and Red Race, and how black, Negro and slave were related in meaning. The fact that students' first response is on the language used in the text shows and indicates their understanding on that work is much influenced on their understanding on the language. It shows that they really have to pay attention on the language, and readers and the text are really interacting.

The second is all students mention that the autobiography has showed them the actual living as a slave and slave's life journey in the era of slavery. The depictions are about how slaves were living in very small cabin among other slaves; being slaves was a descendent from their parents and it would be like that until they fought for their freedom; slaves did not get any appropriate treatment and education; and slaves had to struggle. Some added that it teaches the meaning of life that it was full of struggle whether we were black or not. It seems that life struggle has been seen as the universal value that the readers/students can take and agree with. Further response that students gave was they learnt something from the history of United States better than before. It remarks their interpretation that the autobiography could give them comprehensive understanding on slavery as it is written by a former slave. In conclusion, genre of a literary work does influence the way the students perceive the meaning and interpretation over it. It is an autobiography and they trust it as a real depiction of slavery life.

The last one is actually referring to the same conclusion as the second response has. The readers realized that the autobiography gives the readers/ students details fight and struggle that a slave had to face to achieve his dreams. Fight and struggle mentioned by the readers are struggling for being freemen, gaining proper education, and having the equality for the freedom of expression. Students have marked this and interpreted that Washington's autobiography $U_{p}$ from Slavery has really showed the sequences of detailed struggling from being a 
slave to be a freeman, and, indeed, to succeed his dreams written in every chapter they have read. It could be said that the last response given is much related to readers' ultimate comprehension, and short of conclusion, that they could acknowledge until the end of the discussion and the teaching and learning process.

During the study of Washington's autobiography Up from Slavery by employing reader-response theory i.e. by generating the readers/ students' responses for four classroom meetings, the teacher who happens to be the researcher has seen students' interaction and collaborative cooperation in a way they give the responses, disagree with others' opinions, and, somehow compete each other. Besides, the researcher is able to note that students are quite honest with their being confused, their misunderstanding, and other barriers that have occurred e.g. vocabulary and term barriers and historical background. To sum up, the main point and benefits of understanding the similar resonance between reader-response theory and learners-centered learning could be achieved by the conduct of this classroom. For four meetings, students have created their interpretation and meaning to study Washington's autobiography Up from Slavery. using their responses whereas the conduct of the study has implemented the learners-centered learning that the teacher has left only a little contribution during the teaching and learning process as it is the students who become the main source of knowledge to study Washington's autobiography Up from Slavery.

\section{G Concluding Points}

Here, this piece of writing has tried to argue the possibilities of studying literature from a different point of view e.g. reader-response theory and of teaching and learning literature using a slight various method of teaching e.g. learnerscentered classroom. As a conclusion, the study of the work namely Booker $\mathrm{T}$ Washington's autobiography Up from Slavery is done by generating the students' responses into three responses taken as the students' interpretation of the work. Meanwhile, the process of gaining those responses is by conducting the learnerscentered classroom by giving students more opportunity to participate in the class: As a result, the former proposal offered in the beginning of this writing might be worth trying and analyzing. Reader-responses theory and its combination with learners-centered leaming could be employed and taken as an alternative of studying, teaching, and learning of literature. 


\section{Bibliography}

Abrams, M.H. The Mirror and the Lamp: Romantic Theory and the Critical Tradition. 1953. Oxford: Oxford University Press.

Bleich, David. Subjective Criticism. 1978. Baltimore: John Hopkins University Press.

Bressler, Charles E. Literary Criticism: An Introduction to Theory and Practice. 1999. New Jersey: Prentice Hall.

Corcoran, Bill and Evans, Emrys (Ed.) Readers, Texts, Teachers. 1987. Portsmouth: Co. Publisher.

Culler, Jonathan. Literary Theory: A Very Short Introduction. 1997.Oxford: Oxford University Press.

Davis, Robert Con, Contemporary Literary Criticism (Modern through Postructuralism) 1986. New York: Longman Inc.

Eagleton, Terry. Literary Theory: An Introduction. 1993. Oxford: Blackwell Publisher.

Endrawara, Suwardi. Metodologi Penelitian Sastra. 2003. Yogyakarta: Pustaka Widyatama.

Keesey, Donald. Context for Criticism Second Edition. 1993. Mountain View: Mayfield Publishing Company.

Makaryk, Irena R. Encyclopedia of Contemporary Literary Theory: Approaches, scholars, Terms. 1993. Canada: University of Toronto Press Incorporated.

McCombs, Barbara L. \& Whisler, Jo Sue. The Learner-Centered Classroom and School. 1997. San Fransisco: John Wiley \& Sons, Inc.

Preston, C. E (Ed.). The Penguin Dictionary of Literary Terms and Literary Theory. 1999. London: Penguin Book.

Selden, Raman and Widdowson, Peter. Contemporary Literary Theory $3^{\text {nd }}$ ed. 1993. Kentucky: University Press of Kentucky.

Thompson, Jack. The significance and Uses of Contemporary Literary Theory for the Teaching of Literature. 1992. Norwood, SA: Australian Association for the Teaching of English.

Tompkins, Jane (ed.). Reader-Response Criticism: From Formalism to Post Structuralism. 1980. Baltimore: John Hopkins University Press.

Wiersma, W. Research Methods in Education: An Introduction (6 ${ }^{\text {th }}$ Ed.). 1995. Boston: Allyn and Bacon. 